\title{
Correction to: Delineation of the Role of Astroglial GABA Transporters in Seizure Control
}

\author{
Arne Schousboe $^{1} \cdot$ Karsten K. Madsen $^{1}$
}

Published online: 17 October 2017

(C) Springer Science+Business Media, LLC 2017

Correction to: Neurochem Res (2017) 42:2019-2023

DOI 10.1007/s11064-017-2188-x

The original version of this article unfortunately contained a mistake. In Fig. 1 two chemical structures are incorrect, namely exo-THPO and $\mathrm{N}$-methyl-exo-THPO. The hydroxyl group $(-\mathrm{OH})$ in the isoxazole ring is missing. The corrected Fig. 1 is given below.

The online version of the original article can be found under doi:10.1007/s11064-017-2188-x.

Arne Schousboe

arne.schousboe@sund.ku.dk

1 Department of Drug Design and Pharmacology, Faculty

of Health and Medical Sciences, University of Copenhagen,

Universitetsparken 2, 2100 Copenhagen, Denmark 
Fig. 1 Structural formulas of selected GABA analogs of restricted conformation acting as inhibitors of GABA transporters. Systematic chemical names can be found in the main text<smiles>CNC1CCCc2onc(O)c21</smiles>

N-Methyl-exo-THPO<smiles>COc1ccc(C(OCCN2CCC[C@@H](C(=O)O)C2)(c2ccc(OC)cc2)c2ccc(OC)cc2)cc1</smiles>

SNAP-5114<smiles>Oc1noc2c1CNCC2</smiles>

THPO<smiles>NC1CCCc2onc(O)c21</smiles>

exo-THPO<smiles>Cc1ccsc1C(=CCCN(C)C1CCCc2onc(O)c21)c1sccc1C</smiles>

(R/S)-EF1502<smiles>Cc1ccsc1C(=CCCN1CCC[C@@H](C(=O)O)C1)c1sccc1C</smiles>

Tiagabine 